\title{
PENERAPAN PEMBELAJARAN KONTEKSTUAL DENGAN TUTOR SEBAYA BERBANTUAN MEDIA AUDIOVISUAL UNTUK MENINGKATKAN HASIL BELAJAR PKn
}

\author{
I Putu Adhi Wibawa ${ }^{1}$, Ketut Dibia ${ }^{2}$ \\ 1,2Jurusan Pendidikan Guru Sekolah Dasar, FIP \\ Universitas Pendidikan Ganesha \\ Singaraja, Indonesia \\ email : adhiwibawa25@gmail.com ${ }^{1}$, dibiaketut@yahoo.com ${ }^{2}$
}

\begin{abstract}
Abstrak
Penelitian ini dilatarbelakangi untuk meningkatkan kualitas pembelajaran di kelas IVA SD Laboratorium Undiksha, Singaraja. Semua siswa kelas IVA sudah memiliki nilai diatas KKM namun nilai siswa kelas IVA masih berada pada kreteria sedang pada Penilaian Acuan Patokan (PAP). Tujuan dari penelitian ini adalah untuk meningkatkan hasil belajar PKn siswa kelas IVA SD Laboratorium Undiksha dengan penerapan pembelajaran kontekstual. Jenis penelitian ini adalah Penelitian Tindakan Kelas (PTK) dengan tahapan perencanaan, pelaksanaan, pengamatan, dan refleksi untuk setiap siklus dan penelitian ini diselesaikan dalam dua siklus. Pengumpulan data hasil belajar PKn dalam penelitian ini dilakukan dengan menggunakan metode tes berbentuk pilihan ganda.Selanjutnya data tersebut dianalisis dengan teknik deskriptif-kualitatif dan deskriptif-kuantitatif. Data hasil penelitian menunjukan pada siklus I data nilai rata-rata hasil belajar PKn 72,26 dengan ketuntasan klasikal 26,3\% siswa berada pada kategori tinggi dan pada siklus II 83,5 dengan ketuntasan klasikal $81,5 \%$ siswa berada kategori tinggi. Dengan demikian, peningkatan hasil belajar PKn sebesar 11,24. Hasil penelitian ini menunjukkan bahwa penerapan pembelajaran kontekstual dengan tutor sebayaberbantuan media audio-visual dapat meningkatkan hasil belajar PKn pada siswa kelas IVA tahun ajaran 2017/2018 di SD Laboratorium Undiksha.
\end{abstract}

Kata kunci: Pembelajaran Kontekstual, Hasil Belajar PKn

\section{Abstract}

This study was made to improve the quality of learning in IVA class Lab School Undiksha, Singaraja. All of the students already reach the minimum score but they are only stay on average criteria. The purpose of this study is to improve result in learning Civic on IVA cstudents of Lab School Undiksha through contextual learning application. This study is classroom action research (PTK) which have four phases: planning, implementation, observation, and reflection.in every cycle and finished in only two cycles. Data collected by using multiple choice test. The data analyzed by descriptive-qualitative and descriptive quantitative techniques. The data of this study showed that in first cycle, student's average score of civic was only 72,26 with classical completeness $26,3 \%$ students already reach the high category. In the second cycle, average score of civic was 83,5 with classical completeness $81,5 \%$ students already reach the high category. So that there is improvement of result in learning by 11,24 . Result of this study shows that application of contextual learning (dengan tutor teman sebaya) assisted by audiovisual media can improve result in learning civic of IVA class students in Lab School Undiksha in academic year 2017/2018.

Keywords: contextual learning, result in learning Civic. 


\section{Pendahuluan}

Pembelajaran PKn di SD mempunyai kedudukan yang penting dalam upaya mempersiapkan siswa menjadi warga negara yang memiliki komitmen kuat dan konsisten untuk mempertahankan Negara Kesatuan Republik Indonesia. Oleh karena itu, pembelajaran PKn diarahkan untuk membentuk warga negara yang memahami dan mampu melaksanakan hak - hak dan kewajibannya menjadi warga negara yang baik, cerdas, terampil dan berkarakter sesuai dengan Pancasila dan UUD 1945.

Begitu pentingnya peranan PKn seperti yang diuraikan di atas, seharusnya PKn menjadi salah satu muatan pelajaran yang disenangi dan digemari oleh siswa. "Namun sangat disayangkan bahwa dalam aplikasinya, pembelajaran PKn kurang banyak diminati dan dikaji dalam dunia pendidikan dan persekolahan, karena kebanyakan lembaga pendidikan formal dominan pada penyajian materi yang bersifat kognitif dan psikomotorik belaka, kurang menyentuh pada aspek afektif" (Susanto, 2014:228).

Berdasarkan kenyataan di atas, maka diambil keputusan bersama untuk menciptakan pembelajaran PKn yang dapat memaksimalkan potensi akademik yang dimiliki siswa serta siswa tidak hanya tergantung kepada gurunya. Pembelajaran yang demikian dapat terwujud dalam pembelajaran kontekstual dengan tutor sebaya. Pemilihan pembelajaran kontekstual dengan tutor sebaya didukung dengan penelitian yang dilakukan Darma (2013) bahwa "Pengearuh Pendekatan Pembelajaran Kontekstual Terhadap Hasil Belajar PKn Ditinjau dari Minat Belajar Siswa". Pelaksanaan pembelajaran kontekstual di kelas dapat menciptakan kegiatan pembelajaran yang lebih mengaktifkan siswa karena siswa belajar melalui mengalami bukan menghafal.

Jumadi (2003) menjelaskan, landasan filosofi pembelajaran kontekstual adalah konstruktivisme yang menyatakan bahwa pengetahuan tidak dapat ditransfer dari guru ke siswa seperti halnya mengisi botol kosong, sebab otak siswa tidak kosong melainkan sudah berisi pengetahuan hasil pengalaman-pengalaman sebelumnya. Siswa tidak hanya menerima pengetahuan, namun mengkonstruksi sendiri pengetahuannya melalui proses intra-individual (asimilasi dan akomodasi) dan inter-individual (interaksi sosial).

Adapun tutor sebaya merupakan salah satu metode pembelajaran untuk saling membantu teman yang kurang mampu, sehingga akan terjadi kegiatan belajar yang berlangsung aktif, efektif, komunikatif, dan menyenangkan. Sesuai dengan pendapat yang dikemukkan Bayu Mukti (2009) mengemukan "tutor sebaya adalah suatu metode pembelajaran yang jadi murid dan guru adalah teman sebaya juga atau umumnya itu sebaya".

Rusman (2012: 63) menjelaskan "bahwa media audio-visual yaitu media yang merupakan kombinasi audio dan visual atau bisa disebut media pandang-dengar". Contoh dari media audio-visual adalah program video/televisi pendidikan, video/televisi instruksional, dan program slide suara (sound slide). Peserta didik akan terbantu dengan pemanfaatan media visual melalui indera penglihatan yang dimiliki siswa. Sangat banyak keuntungan kita menggunakan media audio-visual sebagai pembelajaran seperti kegiatan belajar menjadi lebih menarik sehingga siswa tidak cepat bosan, siswa bisa mengembangkan pola pikirnya dan masih banyak lagi.

Menurut Sudjana (2013: 3) "hasil belajar siswa adalah hasil perubahan tingkah laku yang mencakup bidang kognitif, afektif, dan psikomotor". Demikian juga menurut Purwanto (2009:46) "hasil belajar adalah perubahan tingkah laku akibat belajar". Perubahan tingkah laku disebabkan karena mencapai penguasaan atas sejumlah bahan yang diberikan dalam proses pembelajaran. Pencapaian itu atas tujuan pembelajaran yang ditetapkan. Hasil itu dapat berupa perubahan dalam aspek kognitif, afektif, dan psikomotor.

Hasil belajar siswa dipengaruhi oleh dua faktor utama yaitu faktor dari dalam diri siswa dan faktor yang datang dari luar diri siswa atau faktor lingkungan. Slameto (2003:54) mengungkapkan faktor-faktor yang mempengaruhi keberhasilan belajar siswa dapat dibedakan menjadi 2 golongan yaitu: (1) Faktor yang ada pada diri siswa itu sendiri yang disebut faktor individu (intern), yang meliputi a) faktor biologis, meliputi: kesehatan, gizi, pendengaran dan penglihatan, b) faktor psikologis, meliputi: intelegensi, minat dan motivasi serta perhatian 
ingatan berfikir, c) faktor kelelahan, meliputi: kelelahan jasmani dan rohani. (2) Faktor yang ada pada luar individu yang disebut dengan faktor ekstern, yang meliputi a) faktor keluarga. Keluarga adalah lembaga pendidikan yang pertama dan terutama, b) faktor sekolah, meliputi: metode mengajar, kurikulum, hubungan guru dengan siswa, siswa dengan siswa dan berdisiplin di sekolah, c) faktor masyarakat, meliputi: bentuk kehidupan masyarakat sekitar dapat mempengaruhi hasil belajar siswa. Guru yang profesional memiliki kemampuankemampuan tertentu. Keberhasilan siswa dalam belajar akan banyak dipengaruhi oleh kemampuan-kemapuan guru yang profesional. Guru yang profesional adalah guru yang memiliki kompeten dalam bidangnya dan menguasai dengan baik bahan yang akan diajarkan serta mampu memilih metode belajar mengajar yang tepat sehingga pendekatan itu bisa berjalan dengan semestinya.

Pembelajaran kontekstual merupakan suatu proses pembelajaran yang holistik dan bertujuan memotivasi siswa untuk memahami makna pelajaran yang dipelajari dengan mengaitkan materi tersebut dengan konteks kehidupan sehari - hari sehingga siswa memiliki pengetahuan atau keterampilan yang secara fleksibel dapat diterapkan dari suatu permasalahan ke permasalahan lainnya.

Sardiman (2011:222) yang menyatakan, Dalam pembelajaran kontekstual, siswa didorong untuk mengerti makna belajar, apa manfaatnya dan bagaimana mencapainya. Diharapkan siswa menjadi sadar bahwa yang dipelajari berguna bagi hidupnya. Dengan demikian siswa akan memosisikan diri sebagai pihak yang memerlukan bekal untuk hidupnya.

Dalam penerapan pembelajaran kontekstual di dalam kelas harus berlandasan pada komponen-komponen tersebut. Ini seperti yang dijelaskan oleh Zainal (2014:6) bahwa sebuah kelas dikatakan menggunakan pembelajaran kontekstual jika sudah menerapkan ketujuh komponen dalam pembelajarannya. Ketujuh komponen tersebut sebagai berikut: (1) Kontruktivisme, siswa membangun pemahamannya sendiri dari pengalaman berdasarkan pada pengetahuan awal dan pembelajaran harus dikemas menjadi proses mengkontrusksi/membangun bukan menerima pengetahuan. (2) Penemuan/Inkuiry, proses dari perpindahan dan pengamatan menjadi pemahaman dan siswa belajar menggunakan keterampilan berpikir kritis.(3) Bertanya (Questioning), kegiatan guru untuk mendorong, membimbing dan menilai kemampuan berpikir siswa dan bagi siswa merupakan bagain penting dalam pembelajaran berbasis penemuan. (4) Masyarakat belajar (Learning Community), sekolompok orang yang terikat dalam kegiatan belajar, bekerja sama dengan orang lain lebih baik daripada belajar sendiri, tukar pengalaman, dan berbagi ide. (5) Pemodelan (Modeling), proses penampilan suatu contoh agar orang lain berpikir, bekerja dan belajar serta mengerjakan apa yang guru inginkan agar siswa mengerjakannya. (6) Refleksi (Reflection), cara berpikir tentang apa yang telah kita pelajari, mencatat apa yang telah dipelajari, dan membuat jurnal, karya seni, diskusi kelompok. (7) Penilaian yang sebenarnya, (Authentic Asessment), mengukur pengetahuan dan keterampilan siswa, penilaian produk dan tugas tugas yang relevan dan kontekstual.

Damayanti, dkk (2009) mengidentifikasi "tutor sebaya adalah seseorang atau beberapa orang siswa yang ditunjuk oleh guru sebagai pembantu guru dalam melakukan bimbingan terhadap kawan sekelas". Kemudian Uno dan Masri Kuadrat Umar (2010:145) menjelaskan "tutorial antar-angkatan artinya siswa yang lebih senior membantu siswa yang lebih junior. Yang berarti, tutor sebaya adalah siswa yang sebaya membantu teman lainnya yang sebaya juga namun memiliki kemampuan yang kurang".

Tutor sebaya merupakan metode pembelajaran saat siswa belajar dalam kelompok kecil yang dikelompokkan dengan tingkat kemampuan yang berbeda, semua anggota kelompok saling bekerja sama dan membantu untuk memahami bahan materi yang menciptakan saling menghargai sesama teman-teman lainnya. Secara umum kegiatan siswa yang belajar dalam kelompok kecil akan tumbuh dan berkembang dengan pola belajar tutor sebaya (peer group) dan belajar secara bekerja sama (cooperative) (Pustekkom, 2009). Ini sesuai dengan pendapat Sudria dan Manipar Siregar (2000) yang menjelaskan tutor sebaya (peer tutoring) adalah siswa yang lebih mampu membantu siswa yang kurang mampu untuk belajar dalam pasangan- 
pasangan kerja yang kooperatif atau group-group belajar kecil yang secara berhati-hati diorganisir oleh guru profesional.

Jadi, dapat dirangkum pembelajaran dengan tutor sebaya adalah suatu metode pembelajaran yang menempatkan siswa itu sendiri untuk melakukan kegiatan pembelajaran. Siswa yang memiliki kemampuan lebih cepat menyerap materi pelajaran akan bertindak sebagai tutor sebaya untuk membantu siswa lainnya yang kurang cepat menyerap materi pelajaran. Sehingga, dengan pelaksanaan tutor sebaya siswa lebih aktif dalam melakukan diskusi kelompok, karena jika siswa kurang paham dengan materi yang dibahas, siswa harus aktif untuk bertanya dengan tutor sebaya dikelompoknya. Kemudian, karena memiliki usia yang hampir sebaya, adakalanya seorang siswa lebih mudah menerima keterangan yang diberikan oleh siswa lain karena tidak adanya rasa enggan atau malu untuk bertanya.

Media audio-visual merupakan salah satu jenis media pembelajaran yang dapat digunakan dalam proses pembelajaran. Asyhar (2012: 45) Mendefinisikan bahwa media audiovisual adalah jenis media yang digunakan dalam kegiatan pembelajaran dengan melibatkan pendengaran dan penglihatan sekaligus dalam satu proses atau kegiatan. Pesan dan informasi yang dapat disalurkan melalui media ini dapat berupa pesan verbal dan nonverbal yang mengandalkan baik penglihatan maupun pendengaran. Beberapa contoh media audio-visual adalah film, video, program TV dan lain-lain.

Sementara itu Asra (2007: 5) mengungkapkan bahwa "media audio-visual yaitu media yang dapat dilihat sekaligus dapat didengar, seperti film bersuara, video, televisi, dan sound slide". Sedangkan Rusman (2012: 63) menjelaskan "bahwa media audio-visual yaitu media yang merupakan kombinasi audio dan visual atau bisa disebut media pandang-dengar". Contoh dari media audio-visual adalah program video/televisi pendidikan, video/televisi instruksional, dan program slide suara (sound slide).

Berdasarkan penjelasan di atas dapat disimpulkan bahwa media audio-visual merupakan media yang dapat digunakan dalam kegiatan pembelajaran dengan melibatkan pendengaran dan penglihatan sekaligus dalam satu proses atau kegiatan. Contoh media audio-visual adalah film, video, program TV, slide suara (sound slide) dan lain-lain.

Upaya yang dapat dilakukan untuk meningkatkan hasil belajar PKn pada SD Laboratoriun Undikha, dari yang berada pada kriteria sedang menjadi tinggi atau sangat tinggi pada penilaian acuan patokan (PAP) adalah dengan menerapkan model pembelajaran kontekstual dengan tutor sebaya. Model pembelajaran ini menghubungkan konsep pelajaran dengan kehidupan nyata siswa. Dalam kegiatan pembelajaran kontekstual, siswa menkonstruksi dan menemukan sendiri konsep atau pengetahuan yang diterima. Pembelajaran kontekstual memiliki tujuh prinsip yang berorientasi pada siswa yaitu konstruktivisme, inkuiri, bertanya, masyarakat belajar (berkelompok), pemodelan, refleksi siswa, dan penilaian autentik. Melihat dari karakteristik dari pembelajaran kontekstual tersebut sangat cocok dipadukan dengan tutor sebaya, jadi antar siswa terjalin hubungan yang sangat erat dan menumbuhkan rasa percaya diri pada diri siswa. Berhubungan dengan kehidupan nyata siswa media yang cocok untuk menunjang pembelajaran adalah media audio-visual, karena siswa langsung mengalami sehingga pembelajaran menjadi lebih bermakna.

Melalui penerapan pembelajaran kontekstual dengan tutor sebaya berbantuan media audio-visual, diharapkan peningkatan hasil belajar PKn siswa kelas IVA SD Laboratorium Undiksha tahun ajaran 2017/2018.

\section{Metode}

Penelitian yang dilakukan adalah penelitian tindakan kelas (PTK) atau Classroom Action Research dengan pola kolaboratif dengan guru kelas. PTK adalah proses pengkajian masalah pembelajaran di dalam kelas melalui refleksi diri dan upaya untuk memecahkannya dengan cara melakukan berbagai tindakan yang terencana dalam situasi nyata serta menganalisis setiap pengaruh dari tindakan tersebut (Sanjaya, 2014:149).

Penelitian ini dilakukan secara bersiklus dan terdiri dari dua siklus yang dilaksanakan sesuai PTK model Kurt Lewin. Setiap siklus terdapat perencanaan, pelaksanaan, pengamatan, 
dan refleksi (Kusumah, 2012:26). Pada tiap siklus proses pembelajaran dilaksanakan sebanyak 3 kali pertemuan, yang terdiri dari 2 kali pertemuan untuk pelaksanaan tindakan, dan 1 kali pertemuan untuk tes akhir siklus (Arikunto, 2009:21)

Pelaksanaan penelitian dilakukan di SD Laboratorium Undiksha Singaraja pada pembelajaran dengan muatan PKn. Penelitian ini dilaksanakan pada semester II tahun ajaran 2017/2018. Subjek penelitian terdiri dari 38 siswa kelas IVA terdiri dari 18 siswa perempuan dan 20 siswa laki-laki. Objek dalam penelitian ini adalah hasil belajar PKn siswa kelas IVA SD Laboratorium Undiksha dan [pembelajaran kontekstual dengan tutor sebaya berbantuan media audio visual.

Menurut Sugiyono (2013:2) "metode penelitian merupakan cara ilmiah untuk mendapatkan data dengan tujuan dan kegunaan tertentu". Data yang diperlukan dalam penelitian ini adalah data mengenai kompetensi pengetahuan, kompetensi sikap, dan kompetensi keterampilan. Untuk mengumpulkan data dalam penelitian ini digunakan dua metode yaitu: metode tes dan metode nontes. Untuk mengukur muatan PKn digunakan metode tes yakni jenis tes objektif dalam bentuk soal pilihan ganda biasa sebanyak 30 butir soal tiap siklusnya. Sedangkan untuk mengukur kompetensi keterampilan PKn dan kompetensi sikap dalam belajar PKn, metode yang digunakan adalah metode non tes yaitu observasi dengan instrumen lembar pengamatan/observasi. Prosedur penelitian tindakan kelas ini dilaksanakan sampai tercapainya persentase penguasaan kompetensi pengetahuan PKN minimal $80 \%$ siswa berada pada presikat tinggi (80-89) pada skla PAP.

Data yang telah terkumpul kemudian dianalisis dengan metode analisis deskriptif kuantitatif dan metode analisis deskriptif kualitatif. Metode analisis deskritif kuantitatif adalah suatu cara pengolahan data yang dilakukan dengan jalan menyusun secara sistematis dalam bentuk angka-angka dan atau presentase, mengenai suatu objek yang diteliti, sehingga diperoleh kesimpulan umum (Agung, 2012:67). Selanjutnya metode analisis deskriptif kualitatif, Agung (2012:67) menyatakan metode analisis deskriptif kualitatif yaitu suatu cara analisis/pengolahan data dengan jalan menyusun secara sistematis dalam bentuk kalimat/katakata, kategori-kategori mengenai suatu objek (benda, gejala, variabel tertentu), sehingga akhirnya diperoleh kesimpulan umum. Penilaian pengetahuan mengacu pada rentang predikat dalam lampiran Permendikbud No. 53 Tahun 2015 tentang Penilaian Hasil Belajar Oleh Pendidik dan Satuan Pendidikan Pada Pendidikan Dasar dan Pendidikan Menengah, sedangkan untuk kompetensi keterampilan dan kompetensi sikap dilaksanakan sesuai lampiran sesuai dengan Permendikbud No.104 tahun 2014 tentang Penilaian Hasil Belajar.

\section{Hasil Dan Pembahasan}

Sesuai dengan permasalahan yang telah diungkapkan pada bagian pendahuluan, dilaksanakan tindakan dengan menerapakan pembelajaran kontekstual dengan tutor sebaya berbantuan media audio-visual pada tema 8 Daerah Tempat Tinggalku siswa kelas IVA SD Laboratorium Undiksha Singaraja Tahun Ajaran 2017/2018 dengan jumlah subjek sebanyak 38 orang siswa. Data yang terkumpul pada penelitian ini adalah mengenai hasil belajar muatan PKn, aktivitas guru dan aktivitas siswa.

Penerapan pembelajaran kontekstual dengan tutuor sebaya berbantuan media audio visual meningkatkan hasil belajar muatan PKn siswa kelas IVASD Laboratorium Undiksha Singaraja. Hal tersebut terlihat dari peningkatan hasil belajar muatan PKn pada siklus I dan siklus II. Ketuntasan klasikal siswa pada siklus I mencapai 26,3\% siswa nilai muatan PKn berada pada kategori tinggi. Setelah dilaksanakan tindakan siklus II persentase ketuntasan klasikal siswa mencapai 81,5\%siswa nilai muatan PKn berada pada kategori tinggi. Dengan demikian ketuntasan klasikal hasil belajar kompetensi pengetahuan PKn siswa pada siklus I ke siklus II mengalami peningkatan sebesar $55,2 \%$.

Adapun peningkatan tersebut dapat dilihat pada grafik di bawah ini : 


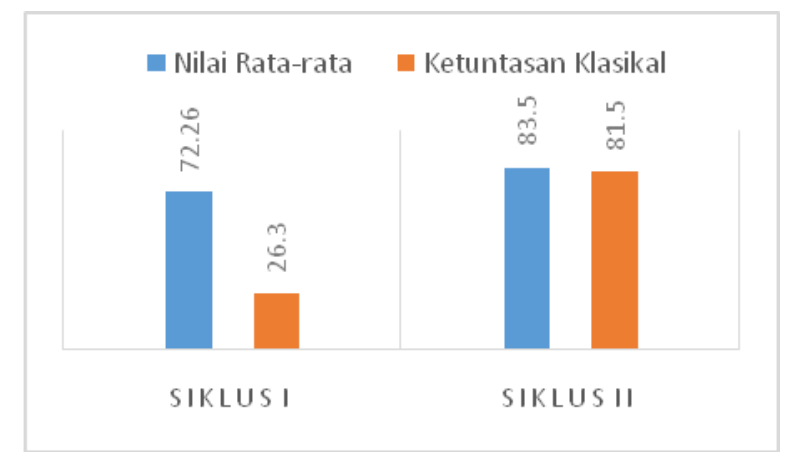

Gambar 01. Grafik Peningkatan Persentase Indikator Pencapaian Hasil Belajar Muatan PKn pada Siklus I dan Siklus II.

Tabel 01.Tabel Rekapitulasi Indikator Pencapaian Data Hasil Belajar Muatan PKn pada Siswa Kelas IVASD Laboratorium Undiksha pada Siklus I, dan Siklus II.

\begin{tabular}{l|c|c|c|c}
\hline \multicolumn{1}{c|}{ Indikator } & $\begin{array}{c}\text { Nilai } \\
\text { Rata-rata }\end{array}$ & Peningkatan & $\begin{array}{c}\text { Ketuntasan } \\
\text { Klasikal }\end{array}$ & Peningkatan \\
\hline Siklus I & 72,26 & 11,24 & $26,3 \%$ & $55.2 \%$ \\
Siklus II & 83,5 & & $81,5 \%$ & 5 \\
\hline
\end{tabular}

Berdasarkan tabel dan grafik tersebut, dapat dilihat telah terjadi peningkatan muatan PKn setelah penerapan pembelajaran kontekstual dengan tutor sebaya berbantuan media audio visual.

Hasil penelitian pada siklus I menunjukan bahwa ketuntasan klasikal muatan PKn hanya mencapai $26,3 \%$ siswa yang berada pada kategori tinggi yang mana belum mencapai indikator keberhasilan hasil belajar muatan PKn yaitu minimal 80\% siswa mendapat nilai 80-89 atau pada kategori tinggi sehingga harus dilanjutkan ke siklus II. Pada siklus II ketuntasan klasikal hasil belajar muatan PKn menjadi 81,5\% meningkat sebanyak 55,2\%. Hail belajar muatan PKn siswa pada pembelajaran siklus II sudah mencapai indikator keberhasilan yang ditetapkan. Jadi, penelitian ini dihentikan pada siklus II.

Selain meningatnya hasil belajar muatan PKn dengan penerapan pembelajaran kontekstual dengan tutor sebaya berbantuan media audio visual, juga meningkatkan aktivitas guru dan aktivitas siswa dalam pembelajaran. Pada aktivitas guru dalam pembelajaran siklus I, jumlah skor yang diperoleh adalah 73,25dari skor maksimal 100 sehingga dikategorikan baik. Oleh karena itu dapat dikatakan bahwa peneliti yang bertindak sebagai guru telah mampu melaksanakan kegiatan pembelajaran dengan baik. Namun masih terdapat beberapa kekurangan yang perlu diperbaiki diantaranya : Guru masih belum bisa memotivasi siswa agar lebih aktif, karena masih ada beberapa siswa yang belum mampu menggunakan alat dan bahan untuk pembelajaran, dan penggelolaan kelas yang belum kondusif, karena siswa masih cenderung rebut pada saat pembelajaran berlangsung sehingga kurang fokus.Pada siklus I terdapat 38 siswa yang hadir. Berdasarkan hasil observasi dapat diketahui bahwa skor ratarata aktivitas belajar siswa adalah 116,5 yang termasuk dalam kategori aktif. Dari catatan yang pada saat pembelajaran beberapa kekurangan di siklus I antara lain: Sebagian siswa kurang aktif dalam pembelajaran di dalam kelompok, Masih ada siswa yang kurang serius dalam pembelajaran, dan Siswa cenderung ribut ketika ada masalah-masalah kecil dalam pembelajaran.

Adapun beberapa indikator yang menunjukkan keberhasilan dalam pembelajaran antara lain, Siswa memperhatikan penjelasan dari guru, Siswa mengerjakan tugas yang diberikan oleh guru, dan Siswa berani bertanya serta berani mengemukakan pendapatnya.

Pada pembelajaran di siklus I masih terdapat beberapa kekurangan yang perlu diperbaiki diantaranya: Guru belum bisa memotivasi siswa agar lebih aktif, karena masih ada beberapa siswa yang belum mampu menggunakan alat dan bahan untuk pembelajaran, dan 
penggelolaan kelas yang belum kondusif, karena siswa masih cenderung rebut pada saat pembelajaran berlangsung sehingga kurang fokus.

Adapun beberapa indikator yang menunjukkan keberhasilan dalam pembelajaran antara lain, Siswa memperhatikan penjelasan dari guru, Siswa mengerjakan tugas yang diberikan oleh guru, dan Siswa berani bertanya serta berani mengemukakan pendapatnya.

Dari hasil analisis data ketuntasan klasikal siswa belum memenuhi indikator keberhasilan yang ditetapkan, karena pada siklus I hanya mencapai $26,3 \%$ atau baru 10 siswa yang nilainya berada rentang 80-89 atau berada pada kategori tinggi dari 29 siswa. Hasil analisis pada siklus I masih belum memenuhi indikator keberhasilan yang ditetapkan, maka dapat dikatakan bahwa pembelajaran muatan PKn pada siklus I dilanjutkan ke siklus II.

Berdasarkan hasil observasi aktivitas guru dalam pembelajaran siklus II, jumlah skor yang diperoleh adalah 82 dari nilai maksimal 100 sehingga dikategorikan sangat baik. Oleh karena itu dapat dikatakan bahwa peneliti yang bertindak sebagai guru telah mampu melaksanakan kegiatan pembelajaran dengan sangat baik.

Perbaikan telah dilakukan dalam menanggulagi kekurangan pada siklus I. Dalam memotivasi, guru mampu mengaitkan pembelajaran dengan kehidupan sehari-hari siswa dan menjelaskan manfaat dari materi yang dipelajari. Kelas yang kurang kondusif dalam pembelajaran dapat dikendalikan dengan membuat aturan-aturan reward-punishment bagi siswa yang aktif dan yang tidak disiplin dalam pembelajaran.

Pada siklus II terdapat 38 siswa yang hadir. Berdasarkan hasil observasi dapat diketahui bahwa skor rata-rata aktivitas belajar siswa adalah 122,5 yang termasuk dalam kategori sangat aktif. Dari catatan yang pada saat pembelajaran beberapa kekurangan di siklus II antara lain, Beberapa kekurangan pada siklus I telah diperbaiki pada siklus II. Masalah keaktifan dan motivasi yang rendah dapat diatasi dengan cara menjelaskan manfaat dari materi pelajaran, serta dengan memberikan reward berupa permen bagi siswa yang aktif. Masalah kedisiplinan dapat diperbaikidengan cara membuat aturan dalam diskusi kelas. Siswa atau kelompok yang ditunjuk untuk memberikan pendapat adalah siswa yang paling disiplin. Berdasarkan data yang diperoleh dari nilai rata-rata hasil belajar muatan PKn siklus I $\vec{X}=72,26$, kemudian pada siklus II nilai rata-rata hasil belajar muatan PKn $\vec{X}=83,5$, sehingga dari siklus I ke siklus II nilai hasil belajar muatan PKn siswa mengalami peningkatan sebesar 11,24. Dengan demikian nilai ratarata hasil belajar muatan PKn telah memenuhi indikator keberhasilan yang ditetapkan yaitu nilai rata-rata hasil belajar muatan PKn mengalami peningkatan. Sedangkan ketuntasan klasikal yang diperoleh siswa pada siklus I yaitu $26,3 \%$ kemudian meningkat pada siklus II menjadi $81,5 \%$. Sehingga dapat dikatakan bahwa ketuntasan klasikal hasil belajar pengetahuan matematika siswa sudah mencapai indikator keberhasilan yang ditetapkan yaitu minimal $80 \%$ dari jumlah siswa memperoleh ketuntasan hasil belajar muatan PKn dengan nilai siswa berada pada rentang 80-89 atau berada pada kategori tinggi pada skala PAP, meskipun masih ada 7 siswa yang masih belum tuntas atau belum mencapai kategori tinggi. Ketujuh siswa tersebut nantinya direkomendasikan ke wali kelas untuk diberikan pembinaaan.

Penelitan ini dilaksanakan di SD Laboratorium Undiksha Singaraja pada siswa kelas IVA semester ganjil tahun pelajaran 2017/2018, banyak siswa kelas IVA adalah 38 siswa yang terdiri dari 18 siswa perempuan dan 20 siswa laki-laki. Pada penelitian ini yang diukur adalah hasil belajar muatan PKn melalui penerapan model pembelajaran kontekstual dengan tutor sebaya melalui media audio-visual. Penelitian ini dirancang melalui beberapa siklus hingga menemukan tindakan yang terbaik. Pada siklus I terdiri dari perencanaan, pelaksanaan, observasi atau evaluasi dan refleksi siklus I, apabila belum berhasil akan dilanjutkan ke siklus II yang terdiri perencanaan, pelaksanaan, observasi atau evaluasi dan refleksi siklus II, apabila berhasil maka penelitian akan dihentikan karena telah mencapai target yang ditentukan.

Hasil penelitian menunjukkan minat belajar pada siklus I belum mencapai kriteria keberhasilan yaitu masih banyak siswa secara individu yang memiliki hasil belajar muatan PKn pada kategori rendah maupun sedang walaupun secara klasikal rata-rata hasil belajar muatan PKn seluruh siswa sudah memenuhi KKM. Hal ini di sebabkan karena ada beberapa siswa yang kurang memperhatikan guru ketika proses pembelajaran berlangsung sehingga hasil 
belajar muatan PKn siswa belum mencapai kriteria keberhasilan yang ditentukan dalam penelitian ini. Maka dari itu segala upaya dirancang untuk menanggulangi kelemahan pada siklus I dan selanjutnya dilaksanakan pada siklus II. Pada siklus II ini segala yang dirancang dan diupayakan berjalan dengan lancar sehingga pada siklus II ini terjadi peningkatan hasil belajar muatan PKn.

Berdasarkan analisis siklus I yaitu persentase ketuntasan klasikal hasil belajar belajar mencapai $26,3 \%$ pada kategori tinggi, maka dari itu pada siklus I indokator keberhasilan yang diharapkan belum tercapai. Sedangkan pada siklus II ketuntasan klasikal mencapai 81,5\% berada pada kategori tinggi, sehingga penelitian ini dihentikan pada siklus II karena indikator keberhasilan sudah tercapai. Hal ini menunjukkan terjadi peningkatan rata-rata kelasdari siklus I ke siklus II dan terjadi peningkatan ketuntasan klasikal secara keseluruhan. Secara umum penelitian ini dapat dikatakan berhasil, karena mampu meningkatkan hasil belajar muatan PKn siswa kelas IVA SD Laboratorium Undiksha Singaraja.

\section{Simpulan dan Saran}

Berdasarkan hasil penelitian dan pembahasan yang telah diuraikan, dapat disimpulkan bahwa penerapan pembelajaran kontekstual dengan tutor sebaya berbantuan media audiovisual dapat meningkatkan hasil belajar muatan PKn siswa kelas IVA semester genap SD Laboratorium Undiksha tahun pelajaran 2017/2018. Hal ini dapat dilihat dari meningkatnya ratarata hasilbelajar muatan PKn pada siklus I yaitu persentase ketuntasan klasikal hasil belajar belajar mencapai $26,3 \%$ pada kategori tinggi, maka dari itu pada siklus I indokator keberhasilan yang diharapkan belum tercapai. Sedangkan pada siklus II ketuntasan klasikal mencapai $81,5 \%$ berada pada kategori tinggi, sehingga penelitian ini dihentikan pada siklus II karena indikator keberhasilan sudah tercapai. Hal ini menunjukkan terjadi peningkatan rata-rata kelasdari siklus I ke siklus II dan terjadi peningkatan ketuntasan klasikal secara keseluruhan.

Sehubungan dengan hasil yang telah dicapai dalam penelitian ini, ada beberapa saran yang dapat sampaikan. Adapun saran tersebut, (1)Diharapkan kepada seluruh siswa khususnya di SD Laboratorium UndikshaSingaraja untuk memanfaatkan pengalaman belajar yang didapat setelah diterapkan model pembelajaran kontekstual dengan tutor sebaya dengan media audio-visualdalam pembelajaran tematiksehingga hasil belajar siswa dapat terus meningkat. (2) Sesuai dengan hasil penelitian tindakan kelas ini, disarankan kepada guru (pengajar) agar dapat mempertimbangkan penerapan model pembelajaran kontekstual dengan tutor sebaya dengan media audio-visual ini sebagai salah satu alternatif pilihan model pembelajaran dalam pembelajaran tematik guna meningkatkan minat belajar dan hasil belajar yang dicapai siswa. (3) Kepada Kepala SD Laboratorium Undiksha Singaraja diharapkan agar hasil penelitian ini dapat dijadikan dasar untuk membimbing dan mengarahkan staf pengajarnya dalam mengelola kegiatan pembelajaran sehingga pelaksanaan kegiatan pembelajaran menjadi lebih efektif. (4) Bagi para peneliti lain yang berminat mengadakan penelitian lebih lanjut dan sejenis tentang penerapan model pembelajaran kontekstual dengan tutor sebaya dengan media audio-visualhendaknya lebih memperhatikan kendala-kendala yang dihadapi siswa dalam pembelajaran serta mengupayakan solusi pemecahan yang tepat agar penelitian yang dilaksanakan dapat mencapai minat belajar yang lebih maksimal sehingga dapat lebih memperkaya strategi pembelajaran.

\section{Daftar Rujukan}

Agung, A.A.Gede. 2012. Metodologi Penelitian Pendidikan. Singaraja: Universitas Pendidikan Ganesha.

-------,2010. Pengantar Evaluasi Pendidikan. Singaraja: Universitas Pendidikan Ganesha.

------. 2014. Metodologi Penelitian Pendidikan. Singaraja: Aditya Media Publishing. 
2016. Statistika Dasar untuk Pendidikan. Yogyakarta: CV Budi Utama.

Aqid, Zainal. 2014. Model - Model, Media dan Strategi Pembelajaran Kontekstual(Inovatif). Bandung: Penerbit Vrama Widya.

Arikunto, Suharsimi, dkk. 2009. Penelitian Tindakan Kelas. Jakarta: PT Bumi Aksara

Djamarah, Syaiful Bahri dan ZainAswan.2006. Strategi Belajar Mengajar. Jakarta: Rineka Cipta.

Damayanti, Elusi, dkk. 2009. "Pendekatan Tutor Sebaya". Tersedia pada http://diskusicagur.blogspot.com/2009/12/pendekatan-tutor-sebaya.html. (diakses tanggal 5 Pebruari 2018).

Mukti, Bayu. 2009. Tutor Sebaya. http://www.bayumukti.com/23032009. (diunduh pada 7 Pebruari 2018)

Sanjaya,Wina. 2014. Strategi Pembelajaran Berorientasi Standar Proses Pendidikan. Jakarta: Kencana, Prendamedia Grup.

Sudjana, Nana. 1997 Media pengajaran penggunaan dan pembuatannya. Bandung: Sinar Baru.

Sugiyono. 2013. Memahami Penelitian Kualitatif. Bandung: Alfabeta.

Susanto, Ahmad. 2014. Teori Belajar dan Pembelajaran di Sekolah Dasar Edisi ke-2. Jakarta: Kencana Prenada Media Group.

Trianto. 2010a. Mendesain Model Pembelajaran Inovatif-Progresif. Jakarta: Kencana Prenada Media Group. 